隣接臟器合併切除で完全切除が得られた肺原発横紋筋肉腫の 1 例

\author{
中嶋 朔生, 吉峯 宗大, 田中 俊樹 \\ 村上 順一, 佐野 史歩, 濱野 公一
}

\begin{abstract}
要旨
肺の悪性腫瘍における肉腫の頻度は約 $0.2 \sim 2.0 \%$ とされ，その中でも成人発症の肺原発横紋筋肉腫は非常に稀である.今 回, 我々は成人発症の肺原発横紋筋肉腫に対して完全切除を成し得た 1 例を経験した. 症例は 70 歳代の男性. 咳嗽を主訴に 近医を受診し，胸部エックス線検査で左上肺野に腫瘤影を指摘された。 CT 検査で左上葉 $\mathrm{S}^{1+2} に 69 \times 56 \mathrm{~mm}$ の腫瘍を認め, CT ガイド下肺生検で spindle cell sarcoma が疑われて当院へ紹介となった. 外科的切除の方針とし, 左上葉切除に加え, 左 下葉 $\mathrm{S}^{6}$ 部分切除および第 $3 \cdot 4$ 肋骨合併切除で完全切除を行い得た. 病理組織検査で肺原発横紋筋肉腫と診断された. 術後 24 力月が経過する現在まで無再発生存中である. 成人発症の肺原発横紋筋肉腫は予後不良な疾患であるが, 外科的完全切除 が唯一の治療法であり, 隣接蔵器合併切除などを要しても完全切除を達成できれば長期生存の可能性がある.
\end{abstract}

索引用語：肺，横紋筋肉腫，手術，成人

pulmonary, rhabdomyosarcoma, surgery, adult

緒言

肺の悪性腫瘍における肉腫の頻度は約 $0.2 \sim 2.0 \%$ とさ れ, その中でも成人発症の肺原発横紋筋肉腫は非常に稀 である．化学療法や放射線療法の有効性は確立されてお らず, 外科的な完全切除が唯一の根治的治療とされてい るが，その予後は不良である。我々は，肺原発横紋筋肉 腫に対して手術を行い, 完全切除を成し得た 1 例を経験 したので報告する。

\section{症例}

患 者: 70 歳代, 男性.

主 訴: 咳嗽.

現病歴：咳嗽のため近医を受診し, 胸部エックス線検 査で左上肺野に腫瘤影を指摘された。 CT 検査で左上葉 $\mathrm{S}^{1+2}$ に $69 \times 56 \mathrm{~mm}$ の腫瘍を認め, CT ガイド下肺生検で

山口大学大学院器官病態外科学呼吸器外科

原稿受付 2020年 5 月 2 日

原稿採択 2020年 6 月 26 日

本論文の要旨は第 36 回日本呼吸器外科学会学術集会にて発 表した。 spindle cell sarcoma が疑われたために当院に紹介と なった。

既往歴：胃潰瘍, 急性虫垂炎術後, 右鼠径ヘルニア術 後.

喫煙歴 : 20 本 $/$ 日 $\times 50$ 年間. 当院受診の 1 力月前から 禁煙.

家族歴：母胃癌, 兄胃癌.

入院時現症：特記すべき異常所見は認めなかった，

血液・生化学検査所見：特記すべき異常所見は認めな かった. 腫瘍マーカーは CEA $8.5 \mathrm{ng} / \mathrm{ml}, \quad$ SLX 56 U/ml と上昇を認めた.

呼吸機能検査所見：VC $3.11 \mathrm{~L}, \% \mathrm{VC} 92.0 \%, F V C 3.12$ L, FEV1.0 2.31 L, FEV1.0\% 74.0\%, \%FEV1.0 86.8\%, DLCO’ $12.30 \mathrm{ml} / \mathrm{min} / \mathrm{mmHg}$, \%DLCO' $84.0 \%$.

胸部エックス線検査所見：左上肺野に $60 \times 57 \mathrm{~mm}$ の 腫瘤影を認めた (Fig. 1).

胸部造影 CT 検査所見：左上葉 $\mathrm{S}^{1+2}$ に $69 \times 56 \mathrm{~mm}$ の 腫瘍性病変を認め, 左下葉 $\mathrm{S}^{6}$ へ浸潤が疑われた（Fig. $2 \mathrm{a}, \mathrm{b})$ ．遠位弓部大動脈との境界は不明瞭であり大動脈 浸潤が疑われた (Fig. 2c). また, 第 $3 \cdot 4$ 肋間の範囲で胸 壁との境界は不明瞭であり胸壁浸潤が疑われた（Fig. 2 


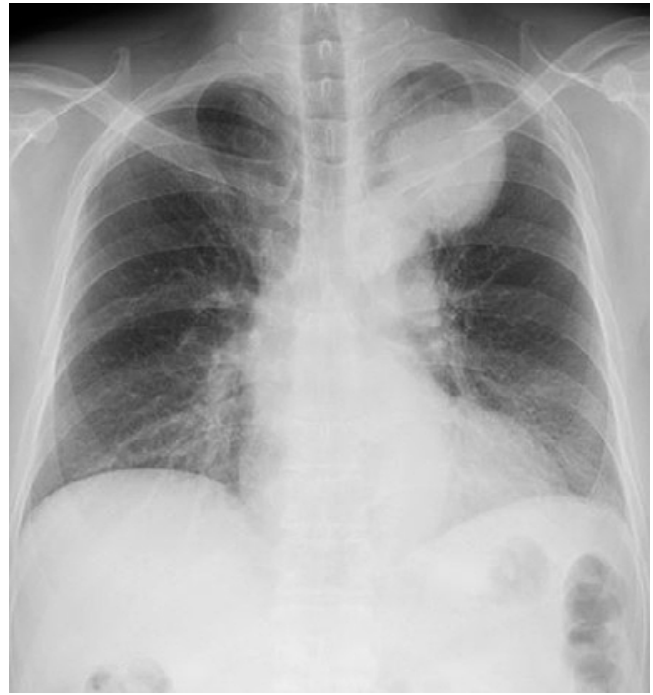

Fig. 1

A chest radiograph showed a large mass shadow in the left upper field. d). 腫大したリンパ節は認めなかった。

PET-CT 検査所見：左上葉の腫瘍に一致して SU$V \max 10.4$ の FDG 集積を認めた.リンパ節転移や遠隔転 移，他病変を疑う所見は認めなかった。

頭頸部 MRI 検査所見：脳転移は認めなかった. MRA では弓部大動脈の分枝に異常は認めなかった。

CT ガイド下肺生検（前医）：クロマチンの増量を伴う 小型で紡錘型の核を有する腫瘍細胞が錯綜状に増生して おり， spindle cell sarcoma が疑われた。

治療方針：胸壁浸潤および大動脈浸潤が疑われたもの の, リンパ節転移や遠隔転移を疑う所見は認めなかった. 最大で胸壁合併切除，遠位弓部大動脈切除再建を行うこ とで完全切除が得られると判断し，手術を行う方針とし た。なお，大動脈浸潤に関しては心臓血管外科医と協議 の上で，大動脈合併切除，人工血管置換を行う準備のも とで手術に臨んだ。CT 検查で左鎖骨下動脈分岐末梢の
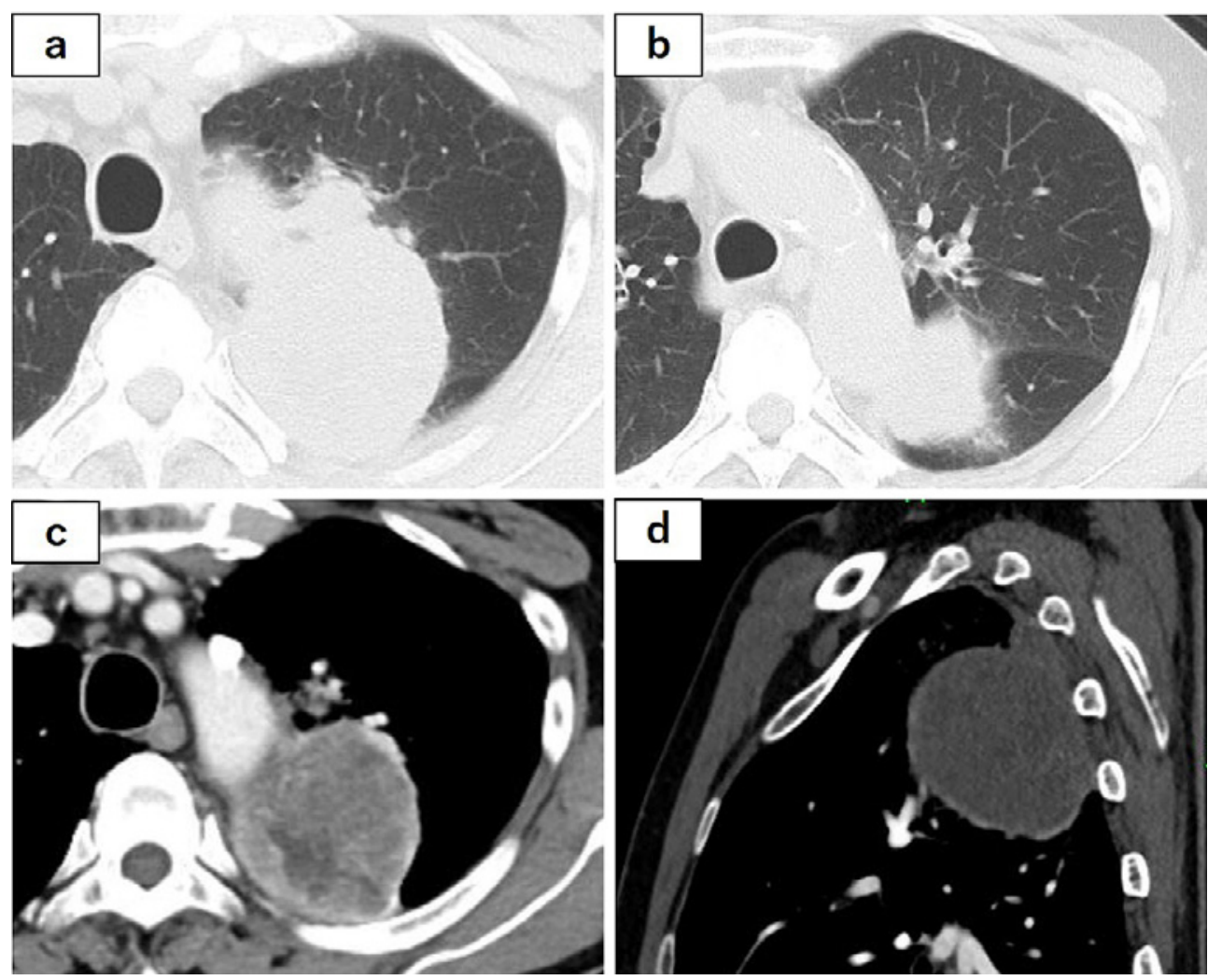

Fig. 2

(a) Chest computed tomography showed a large $69 \times 56 \mathrm{~mm}$ mass in the left $\mathrm{S}^{1+2}$. (b) The mass penetrated the left lower lobe. (c) The border between the mass and distal arch was obscured. (d) The border of the chest wall between the third and fourth ribs was also obscured. 


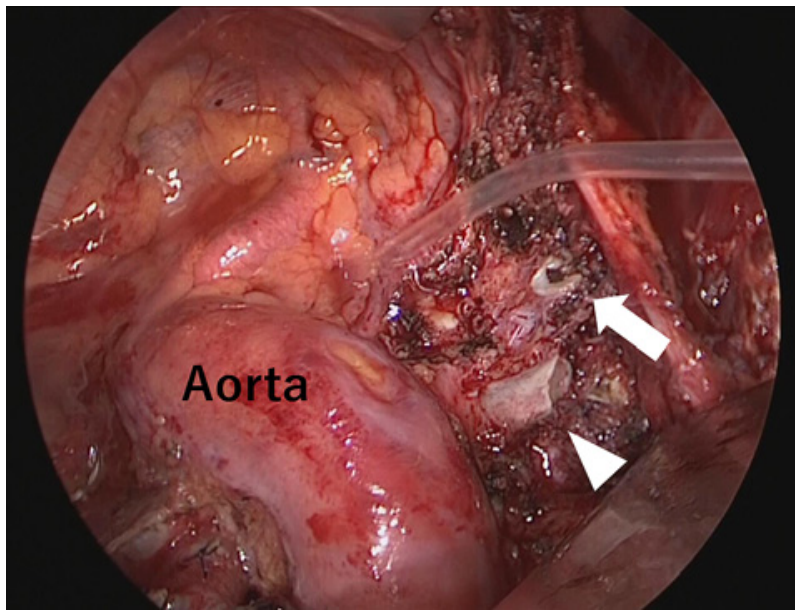

Fig. 3

The third and fourth ribs were resected (arrow: transverse costal fovea of the third thoracic vertebrae, arrowhead: cut end of the fourth rib). Aortic invasion was not observed.

大動脈に石灰化を認めたために，大動脈遮断の中枢側は 左総澒動脈と左鎖骨下動脈の間で, 未梢側は下行大動脈 で行う方針とした. したがって, 送脱血は下行大動脈送 血, 左鎖骨下動脈送血, 肺動脈脱血の予定とした.

手術所見：右側臥位とし，第 7 肋間中腋窩線上にカメ ラポートを留置して胸腔鏡下に腫瘍を観察したところ, 胸壁および左下葉 $\mathrm{S}^{6}$ への浸潤が疑われたが, 胸膜播種は 認められなかった. 根治的手術が可能と判断し, 後側方 切開・第 4 肋間開胸でアプローチした。直接浸潤が疑わ れた第 3,4 肋骨の前方は, 腫瘍から約 $3 \mathrm{~cm}$ のマージン を確保して切断した. 上肺静脈を切離し, 葉間から肺動 脈を剥離した. $\mathrm{A}^{4+5}, \mathrm{~A}^{1+2} \mathrm{c}$ を切離した後に上葉気管支の 切離を行った. 続いて, 中枢側から肺動脈を剥離して $\mathrm{A}^{3}$, $\mathrm{A}^{1+2} \mathrm{a}, \mathrm{A}^{1+2} \mathrm{~b}$ を切離した. 腫瘍と大動脈は鈍的に剥離が 可能であり, 大動脈浸潤は認めなかった. 第 3, 4 肋骨の 肋横突関節を剥離し, 第 4 肋骨は肋横突関節より可及的 に胁骨小頭側で切断し, 第 3 胁骨は胁骨小頭を椎体から 剥離して摘出した (Fig. 3). 最終的には左下葉 $\mathrm{S}^{6}$ および 第 $3 \cdot 4$ 肋骨, 肋間筋を合併切除することで en bloc に切

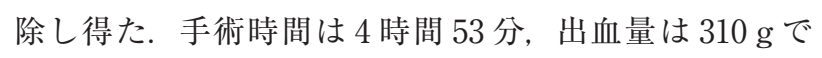
あった。

摘出標本所見：内部に一部壊死を伴う黄白色, 弾性硬 の腫瘍で, 長径 $6.0 \mathrm{~cm} \times$ 短径 $5.6 \mathrm{~cm}$ であった. 腫瘍は被 膜に覆われており周囲組織との境界は明瞭であった (Fig. 4).

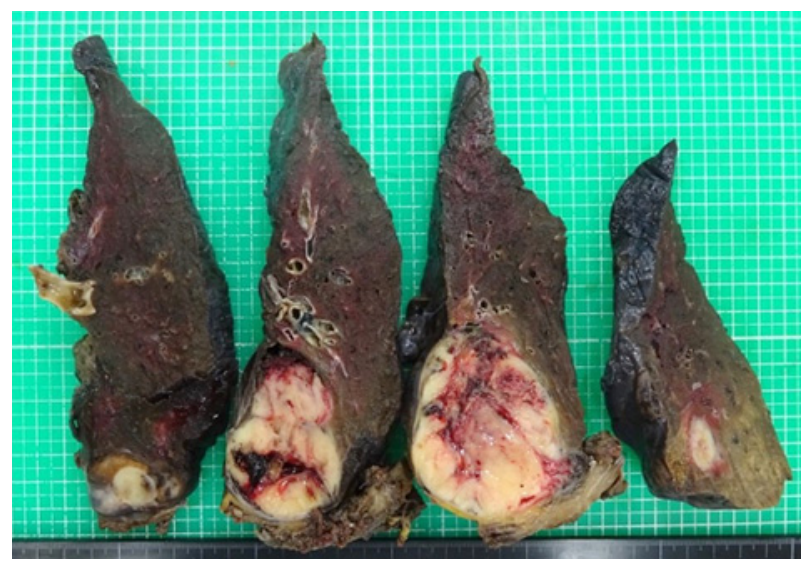

Fig. 4

The tumor was capsular and had clear boundaries, with necrosis in one part of the tumor.

病理組織検査所見：HE 染色の中拡大像 (200 倍)では, 類円形の核を持ち, 胞体の目立たない低分化な紡錘形の 腫瘍細胞が大半を占めており (Fig. 5a), 強拡大像 (400 倍）ではこれらが一部壊死を伴い錯綜構造を示していた (Fig. 5b). 免疫染色では, サイトケラチンのマーカーで ある MNF116, AE1/AE3, CK7, CK5/6, CAM5.2, 平 滑筋のマーカーである $\alpha \mathrm{SMA}$ ，末梢神経のマーカーであ る MPMST, S-100, 脂肪肉腫のマーカーであるCDK4, MDM2 はいずれも除性であった. 間葉系のマーカーであ る Vimentin, 横紋筋のマーカーである Myf-4 (Fig. 5c), Myo-D1（Fig. 5d）はいずれも陽性であった. 上記より肺 原発横紋筋肉腫と診断された。 WHO 分類における組織 型については, 好酸性で紡錘形を示す腫瘍細胞が錯綜配 列を示したこと，また他のどの組織型に特徵的な所見も 認めなかったことから spindle cell/sclerosing type と診 断された. 腫瘍径は $6.0 \mathrm{~cm}, \mathrm{G} 4, \mathrm{pl}, \mathrm{Ly} 0, \mathrm{~V} 1, \mathrm{br}(-)$, pN0, PLC : class II で切除断端はすべて陰性であった.

術後経過：術後 2 日目に胸腔ドレーンを抜去した. 術 後の経過は良好であり, 術後 19 日目に自宅退院となっ た. 術後は無治療で経過観察しており, 術後 24 力月が経 過する現在まで無再発生存中である.

\section{考察}

肺原発の悪性腫瘍における肉腫の頻度は約 0.2 2.0\% とされ ${ }^{1)}$, その中でも平滑筋肉腫, リンパ肉腫や線維肉腫 が多く, 横紋筋肉腫は非常に稀である ${ }^{2)}$. 本来, 肺には横 紋筋組織が存在しないため, その発生機序は不明である. 

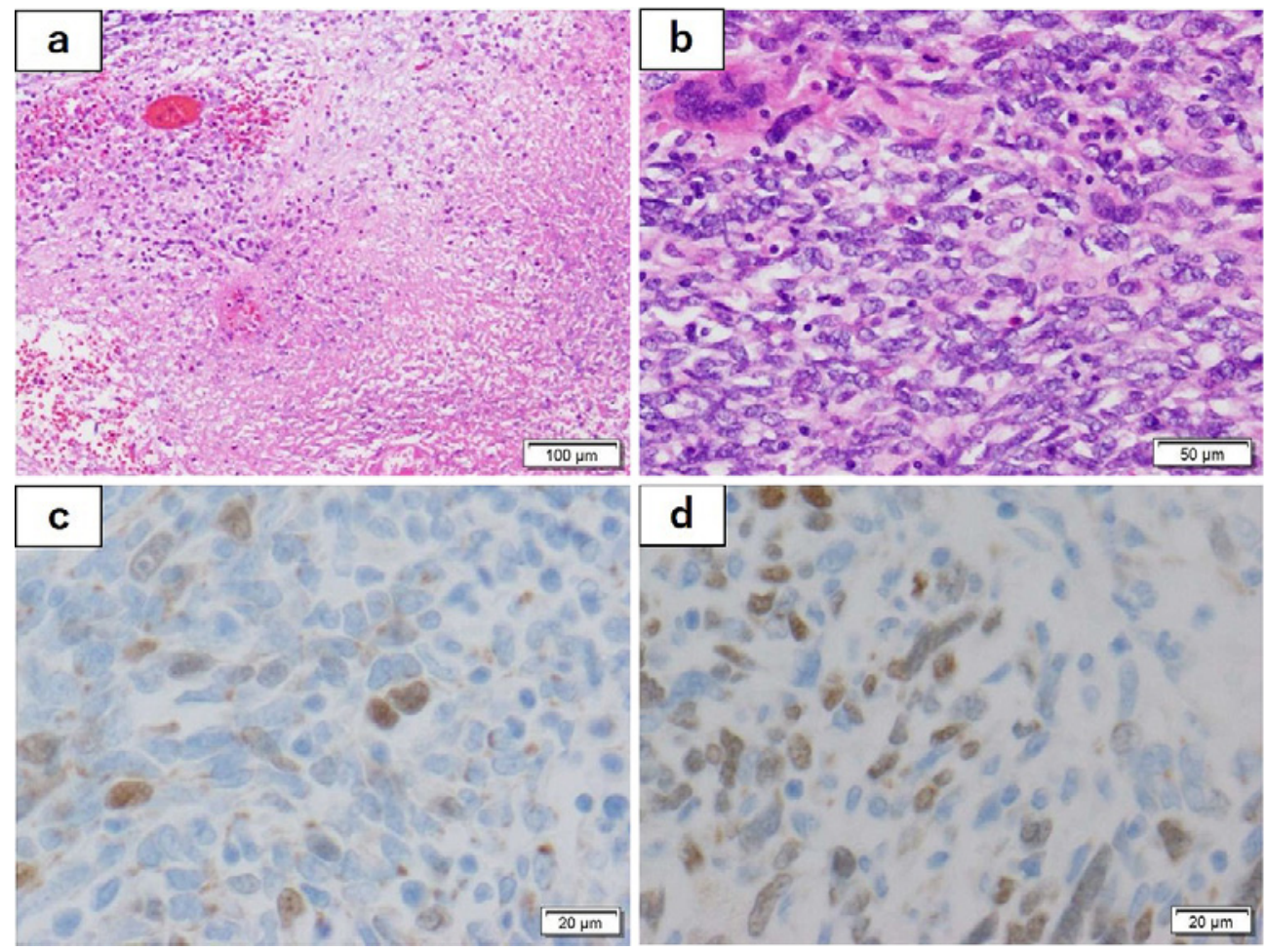

Fig. 5

(a) Necrosis was found in a wide range of lesions (Hematoxylin and eosin [HE] stain $\times 200$ ). (b) The spindle-shaped tumor cells appeared complex with polygonal and malformed nuclear cells (HE stain $\times 400$ ). (c) Tumor cells were immunohistochemically positive for Myf-4 and (d) Myo-D1.

胎生初期に異所性に発生した横紋筋芽細胞が腫瘍化する とする説, 他の間葉系組織から化生した横紋筋組織から 発生するとする説などが提唱されている ${ }^{3}$. 肺原発横紋筋 肉腫の好発年齢は 5 歳以下と 50 歳以上に分かれるとさ れていることからも 異なる可能性があるが, 稀な疾患であることから治療法 や予後など不明確な部分が多い, そこで, 成人発症の肺 原発横紋筋肉腫について, 医中誌で「肺, 横紋筋肉腫」,

PubMed で「pulmonary rhabdomyosarcoma」lung rhabdomyosarcoma」をキーワードに検索し詳細な検討が可 能であった 31 例 (会議録を除く)に本症例を加えた計 32 例を用いて検討した (Table $1^{1,328)}$ ).

男性 25 例, 女性 7 例と男性に多く見られ, 年齢の中央 值は 57.5 歳 (20歳代〜 78 歳)であった. 初発症状は, 咳 嗽, 呼吸困難, 胸痛, 血痰, 体重減少など様々であり, 主に腫瘍の占拠部位によるものと考えられた，また，特 徵的な合併症は指摘できなかった。

横紋筋肉腫はそれぞれの組織学的特徵から embryonal type, alveolar type, pleomorphic type, spindle cell/ sclerosing type の 4 つに分類される ${ }^{29}$. 小监では embryonal type が大半を占めるとされるが30), 成人では pleomorphic type が 20 例, alveolar type が 3 例, embryonal type が 2 例, spindle cell type/sclerosing type が 1 例, 不 明が 6 例と pleomorphic type が最多であった. 成人発症 の肺原発横紋筋肉腫で spindle cell/sclerosing type に分 類された症例は本症例が初であったが, spindle cell/sclerosing type は2013 年の改定により新たに加わったもの であり, 改訂以前の症例に spindle cell/sclerosing type に分類される症例が含まれていた可能性は否定できな い. 実際に, 島田らが報告した embryonal type の 1 例は 線維芽様細胞や紡錘形細胞が索状となって互いに錯綜配 列を示していたことから ${ }^{10)}$, 現在では spindle cell/sclerosing type に分類される可能性も考えられる.

治療法については, 成人では化学療法や放射線治療へ の感受性は低く, 外科的完全切除が唯一の根治的治療で あるとされる ${ }^{11,22)}$. 本検討では手術が施行されなかった症 例は 14 例で, 緩和的治療が 8 例, 化学療法のみが 3 例, 化学放射線療法が 3 例であった。 予後が記載されていた 
Table 1 Cases of primary pulmonary rhabdomyosarcoma

\begin{tabular}{|c|c|c|c|c|c|c|c|c|}
\hline Year & Author & Age & Sex & Histology & Therapy & Follow-up & $\begin{array}{l}\text { Out- } \\
\text { come }\end{array}$ & $\begin{array}{l}\text { Postoperative } \\
\text { recurrence }\end{array}$ \\
\hline 1965 & Conquest $^{3)}$ & 53 & $\mathrm{M}$ & Pleomorphic & Surgery & 152 months & Dead & No \\
\hline 1965 & Conquest ${ }^{3)}$ & 55 & M & Pleomorphic & Surgery & 40 months & Alive & No \\
\hline 1965 & Conquest ${ }^{3)}$ & 66 & $\mathrm{~F}$ & Pleomorphic & Surgery & 20 months & Alive & Lung metastasis \\
\hline 1970 & Itano $^{1)}$ & 55 & $\mathrm{~F}$ & Pleomorphic & Surgery & 12 months & Alive & No \\
\hline 1972 & Furuse ${ }^{5)}$ & 65 & M & Pleomorphic & $\mathrm{CT}$ & 3 months & Dead & - \\
\hline 1975 & Cameron' ${ }^{6)}$ & 56 & M & Pleomorphic & Surgery & 4 months & Dead & No \\
\hline 1976 & Grouls ${ }^{7)}$ & 55 & M & Pleomorphic & Supportive & 3 weeks & Dead & - \\
\hline 1981 & Lee $^{8)}$ & 69 & $\mathrm{M}$ & Pleomorphic & Supportive & 20 days & Dead & - \\
\hline 1984 & Avagnina9) & 43 & M & NS & Surgery & 23 months & Alive & Small bowel metastasis \\
\hline 1985 & Shimada10) & 64 & M & Embroyal & Surgery & 8 months & Dead & Lymph node metastasis \\
\hline 1986 & Miyake 11$)$ & 68 & M & Pleomorphic & Surgery $+\mathrm{CT}$ & 3 months & Dead & Brain metastasis \\
\hline 1993 & Yagi12) & 70 & $\mathrm{M}$ & NS & Supportive & 80 days & Dead & - \\
\hline 1995 & Przygodzki13) & 57 & $\mathrm{M}$ & Pleomorphic & Supportive & Few days & Dead & - \\
\hline 1995 & Przygodzki13) & 58 & $\mathrm{M}$ & Pleomorphic & Supportive & Few days & Dead & - \\
\hline 1995 & Przygodzki13) & 78 & $\mathrm{M}$ & Pleomorphic & Supportive & 24 months & Dead & - \\
\hline 1999 & Klepetko ${ }^{14)}$ & 50 & $\mathrm{~F}$ & NS & Surgery & 2 months & Dead & (Incomplete resection) \\
\hline 1999 & Akakura15) & 64 & $\mathrm{M}$ & NS & Surgery & NS & NS & NS \\
\hline 1999 & Yonezawa ${ }^{16)}$ & 70 & $\mathrm{M}$ & Pleomorphic & Surgery & NS & NS & NS \\
\hline 2000 & Nomura ${ }^{17)}$ & 77 & $\mathrm{M}$ & Embroyal & Supportive & 5 months & Dead & - \\
\hline 2000 & Badreddine ${ }^{18)}$ & 52 & $\mathrm{~F}$ & NS & Surgery & NS & NS & NS \\
\hline 2001 & Comin 19$)$ & 62 & M & Pleomorphic & Surgery + RT & 9 months & Alive & No \\
\hline 2003 & Gray 20$)$ & 40 & $\mathrm{M}$ & Pleomorphic & $\mathrm{CT}+\mathrm{RT}$ & 2 months & Dead & - \\
\hline 2005 & Ludike $^{21)}$ & 43 & $\mathrm{~F}$ & Pleomorphic & Surgery + CT + RT & Few months & Dead & Multiple metastasis \\
\hline 2007 & Gupta $^{22)}$ & 38 & $\mathrm{M}$ & Pleomorphic & Surgery $+\mathrm{CT}+\mathrm{RT}$ & 10 weeks & Dead & (Incomplete resection) \\
\hline 2009 & Choi $^{23)}$ & 44 & M & Pleomorphic & Surgery + CT & NS & NS & $\mathrm{NS}$ \\
\hline 2009 & Kida $^{4)}$ & 64 & $\mathrm{M}$ & Pleomorphic & Supportive & 1 month & Dead & - \\
\hline 2013 & $\mathrm{Ji}^{24)}$ & 51 & $\mathrm{M}$ & Alvelor & $\mathrm{CT}$ & 8 months & Dead & - \\
\hline 2017 & Chaddha ${ }^{25)}$ & 49 & $\mathrm{~F}$ & NS & $\mathrm{CT}$ & NS & NS & - \\
\hline 2018 & Kandola 26$)$ & $20 \mathrm{~s}$ & M & Alvelor & $\mathrm{CT}+\mathrm{RT}$ & NS & Dead & - \\
\hline 2019 & Nishioka ${ }^{27)}$ & 66 & $\mathrm{~F}$ & Alvelor & Surgery + CT & 9 months & Alive & No \\
\hline 2019 & Sun 28$)$ & 75 & M & Pleomorphic & $\mathrm{CT}+\mathrm{RT}$ & 12 months & Alive & - \\
\hline 2020 & Our case & 70 & $\mathrm{M}$ & $\begin{array}{l}\text { Spindle cell } \\
\text { /sclerosing }\end{array}$ & Surgery & 24 months & Alive & No \\
\hline
\end{tabular}

NS, not specified; CT, chemotherapy; RT, radiotherapy.

12 例のうち 11 例が原病死しており, その生存期間中央 值は 2 力月（数日〜 24 力月）であり手術が施行されな かった症例の予後は不良であった。一方, 手術が施行さ れた 18 例は, 手術のみが施行された症例が 12 例, 術後 に化学療法が施行された症例が 3 例, 術後に放射線療法 が施行された症例が 1 例, 術後に化学放射線療法が施行 された症例が 2 例であった。予後が記載されていた 14 例の生存期間中央值は 9 力月（2 力月～12 年 8 力月）で あり，本症例を含めて無再発での長期生存例も散見され $た^{3.9 .27)}$. 以上より, 肺原発横紋筋肉腫に対しては外科的完 全切除が第一選択と考えられる．本症例では腫瘍の大部
分は被膜で覆われており，直接浸潤が疑われた左下葉 $\mathrm{S}^{6}$ および第 $3 \cdot 4$ 肋骨を合併切除することで腫瘍からの切 除マージンを確保した。また，病理組織学的にも切除断 端は陰性であり，摘出したリンパ節にも転移を認めな かったことから, 完全切除を成し得たと判断した. また, 術後補助療法の有効性は確立していないことから，術後 は無治療で経過観察しているが，現在まで再発は認めて いない.

成人発症の肺原発横紋筋肉腫は, 外科的完全切除の成 否が予後に大きく影響することが示唆されたが，非常に 稀な疾患であるために不明確な部分が多く, 今後の更な 
る症例の蓄積が期待される. 特に, 本症例は spindle cell/ sclerosing type の肺原発横紋筋肉腫としては小児を含め て初の報告例であり, 今後も慎重に経過観察を行う必要 があると考えている.

\section{結語}

今回我々は, 成人発症の肺原発横紋筋肉腫に対して手 術を行い，完全切除を成し得た 1 例を経験した。成人発 症の肺原発横紋筋肉腫は予後不良な疾患であるが，外科 的完全切除が唯一の治療法であり, 隣接臟器合併切除な どを要しても完全切除を達成できれば長期生存の可能性 がある。

\section{謝 辞}

最後に, 本症例の病理組織学的診断にご尽力いただい た当院病理検査部星井嘉信先生に媣謝致します。

\section{利益相 反}

共著者の濱野公一は，2017 年に泉工医科工業（株）， エドワーズライフサイエンス (株), 大塚製薬（株），塩 野義製薬(株)，ジョンソン・エンド・ジョンソン(株), セント・ジュード・メディカル(株), 大鵬薬品工業(株), 中外製薬(株)，テルモ(株)，日本メドトロニック(株)， 日本ライフライン (株)，ファイザー(株)，2018 年にア ボットメデイカルジャパン(株)，エドワーズライフサイ エンス(株), 大塚製薬(株), 桂商事(株), ジョンソン・ エンド・ジョンソン (株), 大鵬薬品工業（株），中外製 薬（株），テルモ(株)，日本イーライリリー(株)，日本 ゴア（株），日本メドトロニック(株)，日本ライフライ ン (株), 2019 年に大塚製薬（株），日本ゴア (株)，エド ワーズライフサイエンス (株), 大鵬薬品工業 (株), 中 外製薬（株），日本イーライリリー（株），日本メドトロ ニック（株）より奨学（奨励）寄附を得ている.

\section{文献}

1. 板野龍光, 小西忠司, 小谷澄夫, 野々山明, 香川輝正, 泉 春暁. 原発性肺横紋筋肉腫の 1 例, および本邦の肺肉腫例 について. 日胸外会誌 1970; 18: 1118-25.

2. Petrov DB, Vlassov VI, Kalaydjiev GT, Plochev MA, Obretenov ED, Stanoev VI, et al. Primary pulmonary sarcomas and carcinosarcomas - postoperative results and comparative survival analysis. Eur J Cardiothorac Surg
2003; 23: 461-6.

3. Conquest HF, Thornton JL, Massie JR, Coxe JW 3rd. Primary pulmonary rhabdomyosarcoma: report of three cases and literature review. Ann Surg 1965; 161: 688-92.

4. 木田陽子, 片上信之, 富井啓介, 石原享介, 高橋 豊, 今 井幸弘. 血性胸水貯留で発症し診断に難渋した肺横紋筋 肉腫の 1 例. 日呼吸会誌 2009; 47: 404-9.

5. 古瀬清行, 福岡正博, 小林庸次, 杉本浩一. 腎癌を重複し, その中に転移をみた原発性肺横紋筋肉腫の 1 剖検例。癌 の臨 1972; 18: 279-84.

6. Cameron EW. Primary sarcoma of the lung. Thorax 1975; 30: 516-20.

7. Grouls V, Helpap B. Pulmonary rhabdomyosarcoma. Thoraxchir Vask Chir 1976; 24: 94-7.

8. Lee SH, Rengachary SS, Paramesh J. Primary pulmonary rhabdomyosarcoma: a case report and review of the literature. Hum Pathol 1981; 12: 92-5.

9. Avagnina A, Elsner B, De Marco L, Bracco AN, Nazar J, Pavlovsky H. Pulmonary rhabdomyosarcoma with isolated small bowel metastasis: a report of a case with immunohistochemical and ultrastructural studies. Cancer 1984; 53: 1948-51.

10. 島田勝政, 島田篤子, 山本 寛, 玉田二郎. 肺原発横紋筋 肉腫の 1 例一および本邦報告例の文献的考察一. 病理と 臨 1985; 3: 676-81.

11. 三宅正幸, 伊藤元彦, 和田洋巳, 光岡明夫, 人見滋樹, 渡 辺 智. ミオグロブリンの証明により, 確定診断できた肺 原発横紋筋肉腫の 1 例。日胸外会誌 1986; 34: 2134-7.

12. 八木 大, 長尾修自, 近藤隆史, 曽我部一郎, 津島久孝, 松浦達雄。肺原発横紋筋肉腫の 1 例。回生病医誌 1993; 2: $51-3$.

13. Przygodzki RM, Moran CA, Suster S, Koss MN. Primary pulmonary rhabdomyosarcomas: a clinicopathologic and immunohistochemical study of three cases. Mod Pathol 1995; 8: 658-61.

14. Klepetko W, Wisser W, Birsan T, Mares P, Taghavi S, Kupilik N, et al. T4 lung tumors with infiltration of the thoracic aorta: is an operation reasonable? Ann Thorac Surg 1999; 67: 340-4.

15. 赤倉由佳理, 上村良一, 小林 健, 高島 力, 渡辺洋宇, 野々村昭孝。肺原発肉腫の 3 例 MRI 所見を中心に。臨 放 1999; 44: 851-4. 
16. 米澤和之, 西脇正美, 辻 福正, 古賀昭夫, 平田勇三, 吉 川俊紀, 他. 興味ある画像所見を呈した肺原発横紋筋肉腫 の 1 例. 甲南病医誌 1999; 19:71-4.

17. 野邑浩一, 井本泰樹, 中込幸一, 小川 裕, 宮川政久, 松 本俊治. Primary Pulmonary rhabdomyosarcoma の一症 例. 川崎医師会医会誌 2000; 17: 85-90.

18. Badreddine J, Ledoux JP, Marcade E, Caulet-Maugendre S. Primary pulmonary rhabdomyosarcoma: a case report. Ann Pathol 2000; 20: 66-8.

19. Comin CE, Santucci M, Novelli L, Dini S. Primary pulmonary rhabdomyosarcoma: report of a case in an adult and review of the literature. Ultrastruct Pathol 2001; 25: 269-73.

20. Gray JA, Nguyen GK. Primary pulmonary rhabdomyosarcoma: diagnosed by fine-needle aspiration cytology. Diagn Cytopathol 2003; 29: 181-2.

21. Ludike A, Knolle J, Schon R, Hinze P, Hofmann HS, Schreiber J. Primary pulmonary rhabdomyosarcoma as a rare differential diagnosis of small cell lung cancer. Pneumologie 2005; 59: 456-60.

22. Gupta A, Sharma MC, Kochupillai V, Kichendasse G, Gupta A, Atri S, et al. Primary pulmonary rhabdomyosarcoma in adults: case report and review of literature. Clin Lung Cancer 2007; 8: 389-91.

23. Choi JS, Choi JS, Kim EJ. Primary pulmonary rhabdomyosarcoma in an adult with neurofibromatosis-1. Ann
Thorac Surg 2009; 88: 1356-8.

24. Ji GY, Mao H. Primary pulmonary rhabdomyosarcoma in an adult: a case report and review of the literature. J Zhejiang Univ Sci B 2013; 14: 859-65.

25. Chaddha U, Hagen JA, Yaghmour B. Pulmonary rhabdomyosarcoma associated with check-valve mechanism. Am J Respir Crit Care Med 2017; 196: e7-9.

26. Kandola SK, Rai MP, Rao SL, Marinas EB. Alveolar rhabdomyosarcoma presenting as a lung mass: an uncommon presentation of a less common tumor. BMJ Case Rep 2018; 2018: bcr2018224986.

27. Nishioka Y, Tane S, Nishio W, Tanaka H, Ogawa H, Kitamura Y, et al. A rare resected case of pulmonary rhabdomyosarcoma. Gen Thorac Cardiovasc Surg 2019; 67: 1089-92.

28. Sun KK, Shen XJ. Small bowel metastasis from pulmonary rhabdomyosarcoma causing intussusception: a case report. BMC Gastroenterol 2019; 19: 71.

29. Nascimento AF, Barr FG. Spindle cell/sclerosing rhabdomyosarcoma. In: Fletcher CDM, Bridge JA, Hogendoorn PCW, Mertens F, editors. WHO classification of tumours of soft tissue and bone. Lyon: IARC Press; 2013: $134-5$.

30. Hawkins DS, Spunt SL, Skapek SX. Children's oncology group's 2013 blueprint for research: soft tissue sarcomas. Pediatr Blood Cancer 2013; 60: 1001-8. 


\title{
A case of primary pulmonary rhabdomyosarcoma
}

\author{
Sakuo Nakashima, Sota Yoshimine, Toshiki Tanaka \\ Junichi Murakami, Fumiho Sano, Kimikazu Hamano \\ Department of Surgery and Clinical Science, Division of Chest Surgery, \\ Yamaguchi University Graduate School of Medicine
}

A 70s man presented at a previous hospital with chronic cough. A chest radiograph showed a shadow of a large mass in the left upper lung. Chest computed tomography (CT) showed a large tumor in the left $\mathrm{S}^{1+2}$, with possible invasion of the third and fourth ribs, lower lobe $\left(\mathrm{S}^{6}\right)$, and aorta. Subsequently, CT-guided lung biopsy was performed, and histological analysis suggested spindle cell sarcoma. He was referred to our hospital for surgical resection. We performed a left upper lobectomy with partial resection of the left lobe $\left(\mathrm{S}^{6}\right)$ and third and fourth ribs. Histological examination revealed a primary pulmonary rhabdomyosarcoma (RMS). No lymph node metastases were found, and the resection margin was negative. The postoperative course was uneventful, and he was discharged 19 days after the operation. No recurrence was observed 24 months after the operation. Primary pulmonary sarcomas represent approximately $0.2-2.0 \%$ of all lung malignancies. Adult-onset primary pulmonary RMS is extremely rare. Complete surgical resection is the preferred and only potentially curative treatment. If the tumor is resectable, the surgeon should aim for complete resection, even if combined resection of adjacent organs is necessary.

(C) The Japanese Association for Chest Surgery (JACS) 